Keywords: circulating tumour cells; hepatic resection; colorectal liver metastases; prognostic marker; disease recurrence; CellSearch system

\title{
Prognostic value of circulating tumour cells for early recurrence after resection of colorectal liver metastases
}

\author{
Z S Lalmahomed ${ }^{1}$, B Mostert ${ }^{2}$, W Onstenk ${ }^{2}$, J Kraan $^{2}$, N Ayez ${ }^{3}$, J W Gratama ${ }^{2}$, D Grünhagen ${ }^{3}$, C Verhoef $^{3}$ \\ and S Sleijfer ${ }^{\star}, 2$ \\ ${ }^{1}$ Division of Transplantation and Hepatobiliary Surgery, Department of Surgery, PO Box 2040, Erasmus MC, 3000 CA Rotterdam, \\ The Netherlands; ${ }^{2}$ Department of Medical Oncology and Cancer Genomics Netherlands, Erasmus MC Cancer Institute, \\ PO Box 5201, Erasmus MC, 3008 AE Rotterdam, The Netherlands and ${ }^{3}$ Division of Surgical Oncology, Department of Surgery, \\ Erasmus MC Cancer Institute, PO Box 5201, Erasmus MC, 3008 CA Rotterdam, The Netherlands
}

Background: Despite good outcomes for many, a substantial group of patients undergoing metastasectomy for isolated liver metastases from colorectal cancer (CRC) experience early recurrence. We have investigated whether circulating tumour cell (CTC) detection can identify patients developing disease recurrence within 1 year after liver metastasectomy.

Methods: In CRC patients undergoing liver metastasectomy, $30 \mathrm{ml}$ peripheral blood was withdrawn preoperatively. CTCs were detected by the CellSearch system after a density-gradient-based enrichment step.

Results: One hundred and seventy-three samples from 151 individual patients were analysed. In 75 samples (43\%), CTCs were detected, $16 \%$ had $\geqslant 3$ CTCs $/ 7.5 \mathrm{ml}$ of blood. Eighty-two patients (47\%) experienced early disease recurrence $(<1$ year). The 1-year recurrence rate between patients with or without detectable CTCs were similar (47\% vs $48 \%$ ) or with a low or high CTC count ( $<3$ or $\geqslant 3$ CTCs $/ 7.5 \mathrm{ml}$ of blood) $(50 \%$ vs $47 \%$ ). Also disease-free and overall survival were similar between patients with or without CTCs.

Conclusions: The presence of CTCs in preoperative peripheral blood samples does not identify patients at risk for early disease recurrence after curative resection of colorectal liver metastases. Other parameters are needed to better identify patients at high risk to relapse after liver metastasectomy for CRC.

In Western countries, colorectal cancer (CRC) represents one of the most common malignant diseases and forms a substantial cause of death, frequently due to liver metastases. For patients presenting with isolated colorectal liver metastases (CLM) and disease amenable for complete resection, liver metastasectomy is a potentially curative approach yielding 5-year survival rates, of up to $60 \%$ in highly selected patients (Rees et al, 2008; House et al, 2010). The indications for liver resection have expanded over the past decade due to improvements in surgical techniques, the introduction of more effective systemic chemotherapy and the use of portal vein embolization, radio frequency ablation and stereotactic radiation. And in carefully selected patients, extra-hepatic disease is even no longer a contra-indication for local therapies (Saltz et al, 2000; Azoulay et al, 2000; Hemming et al, 2003; Adam et al, 2004; de Meijer et al, 2006; Mendez Romero et al, 2006; Wong et al, 2010; Chua et al, 2012).

However, despite the good outcomes for many patients undergoing this procedure, there is still a substantial group of patients encountering early recurrence. In a retrospective analysis performed in our centre, the 1-year recurrence rate of CLM after liver resection was almost 50\% (Dols et al, 2009). Obviously, the identification of patients at high risk of disease recurrence after 
surgery for resectable CLM might lead to better selection of patients for this procedure. These patients should either be spared a potentially futile surgery or, their condition permitting, additional and more intensified therapy should be explored to minimise the risk of early relapse.

Circulating tumour cells (CTCs) are cells present in the peripheral circulation of the majority of metastatic cancer patients. Several techniques are currently available for their measurement, but of these, only the CellSearch technique (Veridex LLC, Raritan, NJ, USA) has been approved for use as a prognostic marker in metastatic breast, prostate and CRC cancer by the US Food and Drug Administration. Using this method, the presence of CTCs in peripheral blood of patients has strong prognostic value in various malignancies including metastatic CRC (Mostert et al, 2009; Strijbos et al, 2010; Rahbari et al, 2010; Tol et al, 2010; Stebbing et al, 2014). Most studies on the prognostic value of CTCs in metastatic CRC include patients with irresectable disease treated with chemotherapy (Cohen et al, 2009; Tol et al, 2010; Matsusaka et al, 2011). However, concerning patients with isolated CLM undergoing liver metastasectomy, little is known about the possible prognostic value for CTCs.

The objective of this study was to evaluate whether the detection of CTCs by the CellSearch System can identify patients with resectable CLM undergoing liver metastasectomy who will develop disease recurrence within 1 year after surgery.

\section{PATIENTS AND METHODS}

Patients. Patients over 18 years of age with an adenocarcinoma of the colon or rectum with metastases confined to the liver, confirmed by computed tomography (CT) scan or magnetic resonance imaging (MRI), and eligible for liver resection or 'open' radio frequency ablation therapy (RFA) were included. Patients were excluded if complete resection of the liver metastases was not possible in one procedure, the primary tumour was in situ (liverfirst approach or synchronous resection of primary tumour and liver metastasis), extrahepatic metastasis, histological examination of the liver specimen showed no CLM, or follow-up after resection was $<1$ year. Ours is a referral hospital; preoperative chemotherapy is not administered as a standard treatment protocol for patients with resectable CLM according to the Dutch Guidelines. Most of our patients have already received neoadjuvant chemotherapy in the referring hospital. In our centre, the indication for neoadjuvant chemotherapy is two-fold: in case of initially difficult/unresectable liver metastases, or in case of multiple $(>4)$ synchronous metastases. None of the included patients received adjuvant chemotherapy after the curative liver resection. Clinical data were collected from the medical records and included demographic details, maximum size, number and distribution of liver metastases on CT scan or MRI, plasma carcinoembryonic antigen (CEA) levels, preoperative chemotherapy (chemotherapy administration within 6 months prior to resection), Fong Clinical Risk Score (CRS) (Fong et al, 1999), location, and pathological TNM stage of the primary tumour.

This study was approved by the Ethical Board of the Erasmus MC (METC 2006-089) and all patients gave their written informed consent.

Blood sample analyses. Thirty $\mathrm{ml}$ of blood was drawn from the peripheral arterial line directly preoperatively, before manipulation of the tumour, by the anaesthesiologist in 'CellSave' tubes (Veridex LLC). Samples were stored at room temperature and analysed within $96 \mathrm{~h}$ after collection. The three blood tubes were pooled and then reduced to a volume of $7.5 \mathrm{ml}$ by Ficoll densitygradient separation as previously described (Gross et al, 2005; Lalmahomed et al, 2010). CTCs were enumerated using the
CellSearch System according to the manufacturer's instructions (Allard et al, 2004). Briefly, samples were processed on the semiautomated CellTracks AutoPrep System using the CellSearch Epithelial Cell Kit (both Veridex LLC), which contains magnetic beads coated with anti-epithelial-cell adhesion molecule (EpCAM) antibodies to immunomagnetically enrich epithelial cells from whole blood. Remaining cells are then stained with the nuclear dye $4^{\prime}$,6-diamidino-2-phenylindole (DAPI), anti-cytokeratin (CK) 8/18/19 antibodies labelled with phycoerythrin, and anti-CD45 antibodies labelled with allophycocyanin. After transferral of the sample to a Magnest Cell Presentation Device (Veridex LLC), the cells are scanned by the CellSpotter Analyzer (Veridex LLC), a four-color semi-automated fluorescence microscope. Presented images were assessed by trained readers, and all cells fulfilling all criteria for a CTC-size of $\geqslant 4 \mu \mathrm{m}$, round to oval morphology, positive staining for CK-8/18/19, a visible nucleus (DAPI positive), at least $50 \%$ overlap between nucleus and cytoplasm, and negative staining for CD45-were selected.

Follow-up. After hepatic resection, patients routinely underwent a physical examination and determination of CEA-level, abdominal/ chest CT or ultrasonography every 4 months for the first year, every 6 months the second year and once a year thereafter.

Statistical analysis. The primary end point of this study is disease recurrence within 1 year after hepatic resection for CLM. In a pilot study, $50 \%$ of a patient group with characteristics similar to the population studied here tested positive for the presence of CTCs (Lalmahomed et al, 2010). To detect a 20\% difference in 1-year recurrence rate between patients with detectable CTCs vs those without detectable CTCs with a power of $80 \%$ and a significance level of $5 \%$, knowing that the overall 1 -year recurrence rate is $\sim 50 \%, 200$ patients had to be included.

We use the presence of CTCs ( $\geqslant 1$ CTC) as well as high CTC count ( $\geqslant 3$ CTCs) as cutoff points for analyses in line with Allard et al (2004) and Gazzaniga et al (2013). Categorical data were described as counts with percentages between brackets and continuous data as median with the range between brackets. The $\chi^{2}$-test was used to compare categorical data, for continuous date the independent sample $t$-test and whether data were not equally distributed the Mann-Withney $U$-test was used. Disease-free survival (DFS) was defined as the interval elapsing between the day of surgery to the day of recurrence, death or censoring at most recent follow-up. Overall survival (OS) was the time between the day of surgery and the day of death or censoring at the most recent follow-up. Survival analyses (DFS and OS) were executed following the Kaplan-Meier method, and comparisons were made using the log rank test. A linear regression model was used to evaluate the association between CTC count and the time interval from the last dose of chemotherapy until the operation. In all analyses the significance level was set at $P<0.05$. All the statistical analyses were two sided and carried out using the statistical software package SPSS (IBM Corp. Released 2012. IBM SPSS Statistics for Windows, Version 21.0. Armonk, NY, USA).

\section{RESULTS}

Patients. Blood was drawn from all patients (included in the METC 2006-089 trail) undergoing a liver metastasectomy for isolated CLM, between 1 June 2008 and 31 May 2012. Out of the total 343 blood samples from 289 individual patients collected, 170 samples were excluded (Figure 1). After applying these exclusion criteria, 173 blood samples of 151 individual patients were left for evaluation. Twenty-two patients underwent a second liver resection for recurrent disease confined to the liver following the first resection. Also these samples were included and were considered as separate cases. Patients were divided into two groups according to 
disease recurrence $<1$ year $(n=82)$ and disease recurrence $\geqslant 1$ year or no recurrence $(n=91)$ following hepatic surgery (Table 1$)$. There is a significant difference between the groups in the number of metastases (2 (range 1-10) vs 1 (range 1-8) $P=0.04$ ), as well as the ratio between synchronous, metachronous and recurrent liver metastases, with higher percentages of metachronous metastases in the group with late or no disease recurrence (42\% vs $60 \%$, $P=0.02$ ). Also the distribution of the Fong CRS showed significant difference, which was, as expected, higher in the early-recurrence group (40\% score $3-5$ vs $21 \%, P=0.01)$.

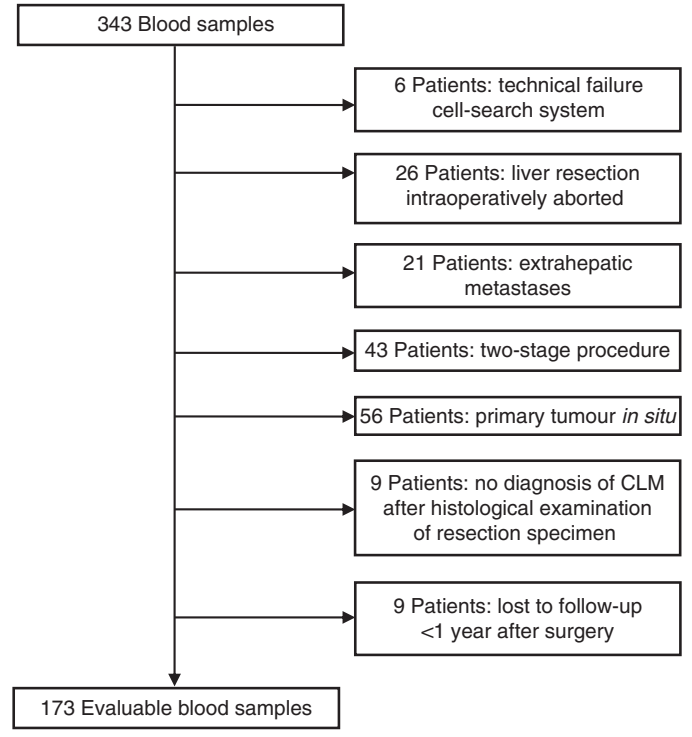

Figure 1. Flow chart sample inclusion.
CTC enumeration and primary end point. In Table 2, the results of the CTC analyses are shown. CTCs were detected in $43 \%$ of the blood samples and the median number of CTCs was zero (range $0-49$ ) in all samples. With respect to the primary objective, there was no significant difference in the 1-year recurrence rate between patients with ( $\geqslant 1$ CTC) or without CTCs ( $47 \%$ vs $48 \%$; $P=0.87)$. The 1-year recurrence rate in the group with $\geqslant 3$ CTCs also showed no significant difference compared with the $<3$ CTC group ( $50 \%$ vs $47 \% ; P=0.76)$. We performed the analyses on a per patient basis as well (151 samples); this showed similar results (data not shown).

Survival analyses. The median follow-up for all 151 patients was 28 months (range 12-59 months), and the median DFS, calculated for every blood sample $(n=173)$, was 14 months (95\% CI 10.917.2 months). Disease recurred in 115 cases (66\%), of which 82 $(47 \%)$ were within 1 year. There was no significant difference in DFS between patients with no or $\geqslant 1$ CTCs $(P=0.56)$ or between those with $<3$ or $\geqslant 3$ CTCs $(P=0.34$, Figure $2 \mathrm{~A}$ and $\mathrm{B})$. During the follow-up period 40 patients $(26 \%)$ died. Survival analyses showed no significant difference in OS between patients with no or $\geqslant 1$ CTCs $(P=0.96)$ or between those with $<3$ or $\geqslant 3$ CTCs, $(P=0.17$, Figure $3 \mathrm{~A}$ and $\mathrm{B})$.

Subgroup analyses. A subgroup analysis was performed for the CTC count between patients who did $(n=80)$ and did not $(n=93)$ receive preoperative chemotherapy. Patients in the preoperative chemotherapy group, received a median number of four cycles of chemotherapy (range 2-12). The median time interval between the last dose of chemotherapy and the operation was 8.6 weeks (range 2.7-38 weeks). The results concerning the CTC count are shown in Table 3. The median CTC count was lower in patients who received chemotherapy $(P=0.05)$ (Figure 4$)$. In $36 \%$ of the patients who received preoperative chemotherapy CTCs were

Table 1. Basic characteristics of the study population divided by recurrence $<1$ year vs no recurrence or later than 1 year

\begin{tabular}{|c|c|c|c|}
\hline \multicolumn{4}{|c|}{ Total inclusion $n=173$} \\
\hline Variable & $\begin{array}{c}\text { Recurrence }<1 \\
\text { year }(n=82)\end{array}$ & $\begin{array}{l}\text { No recurrence or } \\
\text { recurrence } \\
>1 \text { year }(n=91)\end{array}$ & $P$-value \\
\hline Age (years, median (range)) & $63(36-81)$ & $65(37-84)$ & 0.26 \\
\hline Gender (male) & $52(63 \%)$ & 59 (65\%) & 0.85 \\
\hline \multicolumn{4}{|l|}{ Liver metastases } \\
\hline $\begin{array}{l}\text { Number of tumours (median (range)) } \\
\text { Size largest tumour }(\mathrm{cm} \text {, median (range) })^{\mathbf{a}} \\
\text { Bilobar distribution }\end{array}$ & $\begin{array}{l}2(1-10) \\
2.8(0.2-18) \\
27(33 \%)\end{array}$ & $\begin{array}{l}1(1-8) \\
2.6(0.2-10) \\
28(31 \%)\end{array}$ & $\begin{array}{l}0.04 \\
0.24 \\
0.76\end{array}$ \\
\hline \multicolumn{4}{|l|}{ Time to resection } \\
\hline $\begin{array}{l}\text { Synchronous } \\
\text { Metachronous } \\
\text { Recurrence }\end{array}$ & $\begin{array}{l}27(33 \%) \\
34(42 \%) \\
21(25 \%)\end{array}$ & $\begin{array}{l}25(28 \%) \\
55(60 \%) \\
11(12 \%)\end{array}$ & 0.02 \\
\hline \multicolumn{4}{|l|}{ Clinical risk score ${ }^{a}$} \\
\hline $\begin{array}{l}0-2 \\
3-5 \\
\text { Preoperative chemotherapy }\end{array}$ & $\begin{array}{l}46(60 \%) \\
31(40 \%) \\
41(50 \%)\end{array}$ & $\begin{array}{l}69(79 \%) \\
18(21 \%) \\
39(43 \%)\end{array}$ & $\begin{array}{r}<0.01 \\
0.35\end{array}$ \\
\hline \multicolumn{4}{|l|}{ Primary tumour } \\
\hline $\begin{array}{l}\text { Site primary tumour } \\
\text { Colon } \\
\text { Rectum }\end{array}$ & $\begin{array}{l}59(72 \%) \\
23(28 \%)\end{array}$ & $\begin{array}{l}66(73 \%) \\
24(27 \%)\end{array}$ & 0.84 \\
\hline $\begin{array}{l}\text { Tumour-stage primary tumour }{ }^{a} \\
0-2 \\
3-4\end{array}$ & $\begin{array}{l}11(14 \%) \\
69(86 \%)\end{array}$ & $\begin{array}{l}12(13 \%) \\
78(87 \%)\end{array}$ & 0.94 \\
\hline $\begin{array}{l}\text { Lymph node primary tumour }{ }^{a} \\
\text { Positive } \\
\text { Negative }\end{array}$ & $\begin{array}{l}49(60 \%) \\
32(40 \%)\end{array}$ & $\begin{array}{l}45(50 \%) \\
45(50 \%)\end{array}$ & 0.17 \\
\hline
\end{tabular}


Table 2. Results CTC enumeration divided by recurrence $<1$ year vs no recurrence or later than 1 year

\begin{tabular}{|c|c|c|c|}
\hline \multicolumn{4}{|c|}{ Total inclusion $n=173$} \\
\hline Variable & $\begin{array}{l}\text { Recurrence } \\
\quad<1 \text { year } \\
(n=82)\end{array}$ & $\begin{array}{l}\text { No recurrence } \\
\text { or recurrence } \\
\quad>1 \text { year } \\
(n=91)\end{array}$ & $P$-value \\
\hline \multicolumn{4}{|l|}{ CTCs } \\
\hline Number (median, range) & $0(0-28)$ & 0 (0-49) & 0.70 \\
\hline CTCs present & 35 (43\%) & 40 (44\%) & 0.87 \\
\hline$C T C s \geqslant 3$ & $14(17 \%)$ & $14(15 \%)$ & 0.76 \\
\hline
\end{tabular}
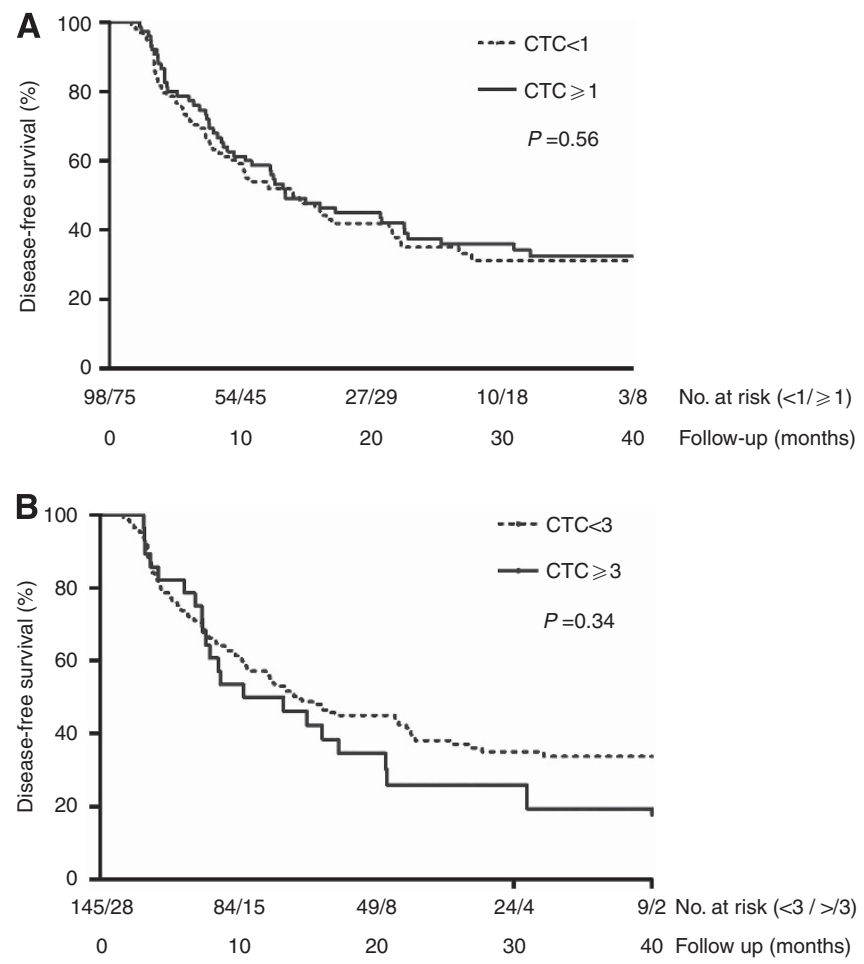

Figure 2. (A) Disease-free survival (DFS) stratified by CTC presence ( $\geqslant 1$ CTC). Median DFS was 13.5 months (95\% Cl 5.9-21.1) when CTCs were present and 14 months (95\% Cl 8.8-19.4) when CTCs were not present. There is no significant difference when the groups are compared $(P=0.56)$. (B) Disease-free survival (DFS) stratified by high CTC count ( $\geqslant 3$ CTC). Median DFS was 10.4 months ( $95 \% \mathrm{Cl} 2.5-18.4$ ) when $\geqslant 3$ CTCs were present and 14.5 months (95\% Cl 7.8-21.3) when there were $<3$ CTCs. There is no significant difference when the groups are compared $(P=0.34)$.

detected ( $\geqslant 1$ CTC), compared with $50 \%$ of patients who did not receive chemotherapy, this difference was not statistically significant $(P=0.08)$. The percentage of patients with a high $(\geqslant 3)$ or low $(<3)$ CTC count also showed no difference between the groups $(P=0.22)$. The 1 -year recurrence rate for patients who received preoperative chemotherapy was not significantly different between patients with or without CTCs present (48\% vs 53\%, $P=0.69)$. There was no association between CTC count and the time interval from the last dose of chemotherapy until the operation (for each week increase in time interval between the last dose of chemotherapy and the operation, the CTC count increases by 0.067 CTCs $(95 \%$ CI: $-0.008,0.142 ; P=0.08$ ). For patients who did not receive preoperative chemotherapy the 1-year recurrence was similar between the group with and without CTCs (46\% vs $43 \%, P=0.76$ ).
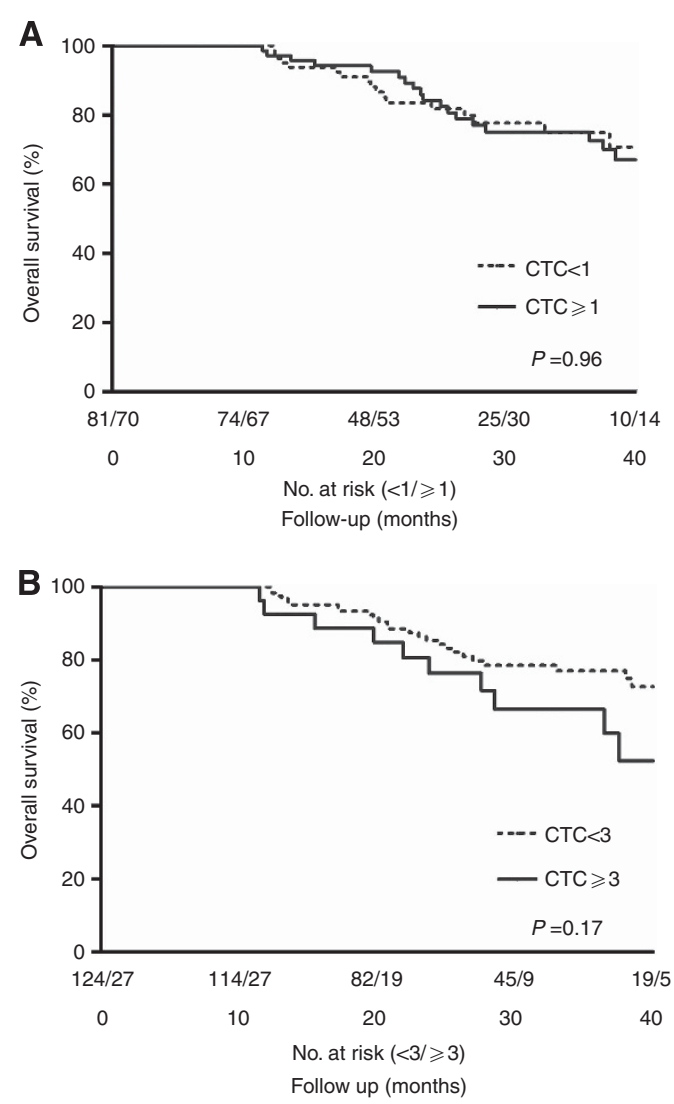

Figure 3. (A) Overall survival (OS) stratified by CTC presence $(\geqslant 1$ CTC). There is no significant difference in CTC presence in relation to overall survival $(P=0.96)$. (B) Overall survival stratified by high CTC count ( $\geqslant 3 \mathrm{CTC}$ ). There is no significant difference in high CTC count in relation to overall survival $(P=0.17)$.

Table 3. Results CTC enumeration divided by preoperative chemotherapy

\begin{tabular}{|c|c|c|c|}
\hline \multicolumn{4}{|c|}{ Total inclusion $n=173$} \\
\hline Variable & $\begin{array}{c}\text { With } \\
\text { preoperative } \\
\text { chemotherapy } \\
(n=80)\end{array}$ & $\begin{array}{c}\text { Without } \\
\text { preoperative } \\
\text { chemotherapy } \\
(n=93)\end{array}$ & $P$-value \\
\hline \multicolumn{4}{|l|}{ CTCs } \\
\hline Number (median (range)) & $0(0-13)$ & $1(0-49)$ & 0.05 \\
\hline CTCs present & $29(36 \%)$ & $46(50 \%)$ & 0.08 \\
\hline CTCs $\geqslant 3$ & 10 (13\%) & 18 (19\%) & 0.22 \\
\hline
\end{tabular}

\section{DISCUSSION}

This study does not demonstrate a prognostic value for CTC enumeration in patients with isolated CLM undergoing a partial liver metastasectomy with a curative intent. The power analysis conducted prior to our study indicated that 200 patients had to be included to show a $20 \%$ difference in the relapse rate at 1 year between patients with $v s$ those without CTCs. Of the 343 patient samples, 170 cases had to be excluded for several reasons including extra-hepatic disease or residual disease after surgery. We excluded these patients as we expected their remnant tumour tissue to influence the course of disease. Nevertheless, despite this slightly reduced power, the DFS curves clearly show no differences in 


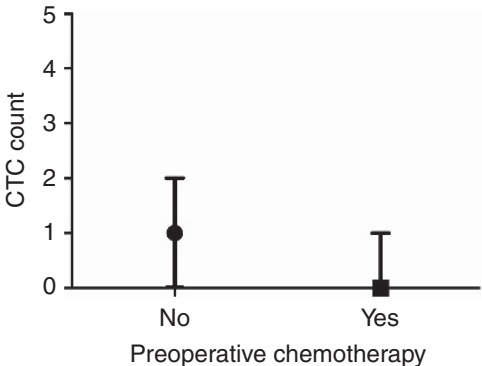

Figure 4. CTC counts in patients who received preoperative chemotherapy $(n=93)$ and patients who did not $(n=80)$, depicted are the medians with the interquartile range.

outcome between patients with $v$ s those without detectable CTCs. We therefore feel that further studies using the same technique and similar study design and setting are not justified as futility has been adequately demonstrated.

The lack of prognostic value of CTC counts in this patient group with limited metastatic disease is in contrast to findings in patients with advanced CRC. In these studies, where the same CTC enumeration technique was used, a CTC count of $\geqslant 3$ per $7.5 \mathrm{ml}$ of blood was associated with a worse progression-free and OS survival among patients with advanced CRC treated with first-, second- or third-line chemotherapy (Cohen et al, 2008; Tol et al, 2010). Importantly, instead of drawing and analysing $7.5 \mathrm{ml}$ of blood as was done in these previous studies, we drew $30 \mathrm{ml}$ of blood and then reduced this to a volume of $7.5 \mathrm{ml}$ of enriched blood by density-gradient separation. We choose this approach as we expected CTC counts to be lower in our patient group with limited metastatic tumour load. The potential benefit of this method was shown in a pilot study among 15 patients, in which more CTCs were detected using $30 \mathrm{ml}$ instead of $7.5 \mathrm{ml}$ blood (median paired difference 1 (range, -1 to 7)) (Lalmahomed et al, 2010). As a consequence, when we compare our CTC counts with other studies detecting colorectal CTCs using CellSearch in $7.5 \mathrm{ml}$ of blood, the difference in blood volume should be taken into account. Despite the higher blood volumes in our study, both the number of patients with CTCs present $(\geqslant 1$ CTC) and the number with a high CTC count $(\geqslant 3)$ is clearly lower in our study population compared with other studies in patients with metastatic CRC. In our study, CTCs were present in $43 \%$ of the patients and $16 \%$ had $\geqslant 3$ CTCs, in the study by Tol et al (2010) $29 \%$ of the patients had $\geqslant 3$ CTCs, Cohen et al (2009) reported $31 \% \geqslant 3$ CTCs and Hiraiwa et al (2008) 41.4\% $\geqslant 2$ CTCs. This difference is likely due to the fact that our study patients have relatively limited metastatic disease, as they had to be eligible for liver surgery with curative intent. This is in stark contrast with the aforementioned other studies, which included patients treated up to third-line chemotherapy and who are therefore likely to have more extended disease. It has been demonstrated that more advanced disease is associated with larger amounts of CTCs (Hiraiwa et al, 2008). Hiraiwa et al (2008) found a significantly higher percentage of patients with $\geqslant 2$ CTCs among patients with metastases confined to the peritoneum compared with patients with metastases to the liver and lung $(64 \%$ vs $26 \%, P<0.01)$. Similar results have recently been published by Kaifi et al (2013); in their case series $60 \%$ of patients with diffuse metastases had CTCs present, in contrast to patients with metastases confined to the lung and the liver $(11 \%$ and $32 \%$ respectively $(P<0.01)$ ).

Numerous articles report on the impact of chemotherapy on CTCs, and in the vast majority of patients undergoing chemotherapy, CTC numbers decline during treatment. (Tol et al, 2010, Neki et al, 2013). To exclude the possibility of the impact of neoadjuvant chemotherapy obscuring the prognostic value of CTCs in this setting, associations were explored in only the patients receiving neoadjuvant chemotherapy as well as those who were untreated before liver metastasectomy. But also in these separate groups, CTC counts had no prognostic value.

Only recently Seeberg et al (2014) published an article were also the CellSearch was used as a method to detect CTCs (in $7.5 \mathrm{ml}$ blood) in patients with isolated CLM. The recurrence rate was similar to our study group. They reported that CTCs can predict nonresectability and impaired survival. CTC positivity was significantly higher in nonresectable (46\%) than in resectable patients (11.7\%), $P<0.01$. Contrary to our findings, patients who underwent resection and with two or more CTCs experienced reduced time to relapse or disease progression $(P<0.01)$. As we used $30 \mathrm{ml}$ blood, had a different, predefined primary end point and used other cutoff values, the studies are not fully comparable. A major difference between the studies is that they also included patients who were not eligible for resection. It is also not clear whether the patients who underwent liver surgery had extrahepatic disease. Therefore our group is more homogeneous (Seeberg et al, 2014).

Three studies have looked in this population (resectable CLM) using other CTC enumeration tests based on RT-PCR assays. Vlems et al (2003) and Topal et al (2005) could not predict disease recurrence in patients with resectable CLM using their CTC detection methods. A third study by Koch et al (2005) did show that intra-operatively detected CTCs were of prognostic value. It should be noted that these studies concerned only small numbers of patients and that the prognostic value found in the latter study is yet to be confirmed. In general, the nature of RT-PCR-based CTC detection assays confers to a higher sensitivity compared with the CellSearch technique, due to the fact that the CellSearch System uses very stringent criteria by which a CTC is defined. In this way, small tumour fragments, apoptotic CTCs or CTCs with low expression of one of the detection markers are not counted as CTCs. This idea is supported by our previous findings in which tumour DNA and RNA could be detected using RT-PCR, whereas using the CellSearch technique in the same blood samples, no CTCs could be detected (Mostert et al, 2013). Especially in patients with low tumour load, more sensitive CTC detection methods such as RT-PCR-based methods should be explored for their value as prognostic marker, while remaining aware of concerns about test specificity. In addition to RT-PCR-based methods, various other techniques to enumerate CTCs have recently been described. In contrast to the CellSearch technique, which among others relies on EpCAM and CK 8/18/19 expression on CTCs to be identified, other methods use size-based enrichment methods and/or other antibodies to detect CTCs. This may lead to a higher sensitivity to detect CTCs in CRC patients. Also these techniques should be explored for their value in this patient setting.

In our study, we have used $30 \mathrm{ml}$ blood that was reduced to $7.5 \mathrm{ml}$ for the CellSearch analyses, with the idea that CTC detection is more frequent when sample volume is larger. This is shown when we compare the data on CTC presence between Seeberg et al (2014) and ours (19.6\% vs 43\%). Coumans et al (2012) investigated different methods to increase the detection of CTCs and undescribed our method. They state that by statistical analysis of the distribution in $7.5 \mathrm{ml}$ of blood detected by CellSearch in patients with metastatic cancer, the sample size should be 51 of blood for the detection of CTCs. Knowing that there are organ systems that have the ability to filter CTCs, there is also the question whether peripheral blood sampling alone is sufficient (Jiao et al, 2009).

In conclusion, in this relatively large study no prognostic value for CTC counts as determined by the CellSearch technique could be found for outcome following liver metastasectomy in patients with resectable isolated CLM. The relatively high relapse rate in this group of patients with $>50 \%$ of the patients relapsing within 1 year again underlines the high need for novel biomarkers to guide treatment in this patient category. 


\section{REFERENCES}

Adam R, Delvart V, Pascal G, Valeanu A, Castaing D, Azoulay D, Giacchetti S, Paule B, Kunstlinger F, Ghemard O, Levi F, Bismuth H (2004) Rescue surgery for unresectable colorectal liver metastases downstaged by chemotherapy: a model to predict long-term survival. Ann Surg 240: 644-657.

Allard WJ, Matera J, Miller MC, Repollet M, Connelly MC, Rao C, Tibbe AG, Uhr JW, Terstappen LW (2004) Tumor cells circulate in the peripheral blood of all major carcinomas but not in healthy subjects or patients with nonmalignant diseases. Clin Cancer Res 10: 6897-6904.

Azoulay D, Castaing D, Smail A, Adam R, Cailliez V, Laurent A, Lemoine A, Bismuth H (2000) Resection of nonresectable liver metastases from colorectal cancer after percutaneous portal vein embolization. Ann Surg 231: 480-486.

Chau TC, Saxena A, Liauw W, Chi F, Morris DL (2012) Hepatectomy and resection of concomitant extrahepatic disease for colorectal liver metastases-a systematic review. Eur J Cancer 48: 1575-65.

Cohen SJ, Punt CJ, Iannotti N, Saidman BH, Sabbath KD, Gabrail NY, Picus J, Morse M, Mitchell E, Miller MC, Doyle GV, Tissing H, Terstappen LW, Meropol NJ (2008) Relationship of circulating tumor cells to tumor response, progression-free survival, and overall survival in patients with metastatic colorectal cancer. J Clin Oncol 26: 3213-3221.

Cohen SJ, Punt CJ, Iannotti N, Saidman BH, Sabbath KD, Gabrail NY, Picus J, Morse MA, Mitchell E, Miller MC, Doyle GV, Tissing H, Terstappen LW, Meropol NJ (2009) Prognostic significance of circulating tumor cells in patients with metastatic colorectal cancer. Ann Oncol 20: 1223-1229.

Coumans FA, Ligthart ST, Uhr JW, Terstappen LW (2012) Challenges in the enumeration and phenotyping of CTC. Clin Cancer Res 18: 5711-5718.

de Meijer VE, Verhoef C, Kuiper JW, Alwayn IP, Kazemier G, Ijzermans JN (2006) Radiofrequency ablation in patients with primary and secondary hepatic malignancies. J Gastrointest Surg 10: 960-973.

Dols LF, Verhoef C, Eskens FA, Schouten O, Nonner J, Hop WC, Mendez Romero A, de Man RA, van der Linden E, Dwarkasing RS, Ijzermans JN (2009) [Improvement of 5 year survival rate after liver resection for colorectal metastases between 1984-2006] Verbetering in 5 -jaarsoverleving na leverresectie voor colorectale metastasen tussen 1984-2006. Ned Tijdschr Geneeskd 153: 490-495.

Fong Y, Fortner J, Sun RL, Brennan MF, Blumgart LH (1999) Clinical score for predicting recurrence after hepatic resection for metastatic colorectal cancer: analysis of 1001 consecutive cases. Ann Surg 230: 309-318.

Gazzaniga P, Raimondi C, Gradilone A, Biondi ZOCCAI G, Nicolazzo C, Gandini O, Longo F, Tomao S, Lo Russo G, Seminara P, Vincenzi B, Chimenti I, Cristofanilli M, Frati L, Cortesi E (2013) Circulating tumor cells in metastatic colorectal cancer: do we need an alternative cutoff? J Cancer Res Clin Oncol 139: 1411-1416.

Gross S, Bui T, Rao C, Connelly M, Terstappen WMM (2005) Modified Ficoll preprocessing procedure for $30 \mathrm{~mL}$ of whole blood prior to cellsearch circulating tumor cell test. 5th International Symposium on Minimal Residual Cancer; 10-13 September; San Francisco, CA, USA.

Hemming AW, Reed AI, Howard RJ, Fujita S, Hochwald SN, Caridi JG, Hawkins IF, Vauthey JN (2003) Preoperative portal vein embolization for extended hepatectomy. Ann Surg 237: 686-691.

Hiraiwa K, Takeuchi H, Hasegawa H, Saikawa Y, Suda K, Ando T, Kumagai K, Irino T, Yoshikawa T, Matsuda S, Kitajima M, Kitagawa Y (2008) Clinical significance of circulating tumor cells in blood from patients with gastrointestinal cancers. Ann Surg Oncol 15: 3092-3100.

House MG, Ito H, Gonen M, Fong Y, Allen PJ, Dematteo RP, Brennan MF, Blumgart LH, Jarnagin WR, D'angelica MI (2010) Survival after hepatic resection for metastatic colorectal cancer: trends in outcomes for 1,600 patients during two decades at a single institution. J Am Coll Surg 210: 744-752.

Jiao LR, Apostolopoulos C, Jacob J, Szydlo R, Johnson N, Tsim N, Habib NA, Coombes RC, Stebbing J (2009) Unique localization of circulating tumor cells in patients with hepatic metastases. J Clin Oncol 27: 6160-6165.

Kaifi JT, Kunkel M, Zhu J, Dicker DT, Gusani NJ, Yang Z, Sarwani NE, Li G, Kimchi ET, Staveley-O'Carroll KF, El-Deiry WS (2013) Circulating tumor cells are associated with diffuse spread in stage IV colorectal cancer patients. Cancer Biol Ther 14: 1174-1181.

Koch M, Kienle P, Hinz U, Antolovic D, Schmidt J, Herfarth C, von Knebel Doeberitz M, Weitz J (2005) Detection of hematogenous tumor cell dissemination predicts tumor relapse in patients undergoing surgical resection of colorectal liver metastases. Ann Surg 241: 199-205.
Lalmahomed ZS, Kraan J, Gratama JW, Mostert B, Sleijfer S, Verhoef C (2010) Circulating tumor cells and sample size: the more, the better. J Clin Oncol 28: e288-e289author reply e290.

Matsusaka S, Suenaga M, Mishima Y, Kuniyoshi R, Takagi K, Terui Y, Mizunuma N, Hatake K (2011) Circulating tumor cells as a surrogate marker for determining response to chemotherapy in Japanese patients with metastatic colorectal cancer. Cancer Sci 102: 1188-1192.

Mendez Romero A, Wunderink W, Hussain SM, de Pooter JA, Heijmen BJ, Nowak PC, Nuyttens JJ, Brandwijk RP, Verhoef C, Ijzermans JN, Levendag PC (2006) Stereotactic body radiation therapy for primary and metastatic liver tumors: a single institution phase i-ii study. Acta Oncol 45: 831-837.

Mostert B, Jiang Y, Sieuwerts AM, Wang H, Bolt-de Vries J, Biermann K, Kraan J, Lalmahomed Z, van Galen A, de Weerd V, van der Spoel P, Ramirez-Moreno R, Verhoef C, Ijzermans JN, Wang Y, Gratama JW, Foekens JA, Sleijfer S, Martens JW (2013) KRAS and BRAF mutation status in circulating colorectal tumor cells and their correlation with primary and metastatic tumor tissue. Int J Cancer 133: 130-141.

Mostert B, Sleijfer S, Foekens JA, Gratama JW (2009) Circulating tumor cells (CTCs): detection methods and their clinical relevance in breast cancer. Cancer Treat Rev 35: 463-474.

Neki K, Kawahara H, Watanabe K, Toyama Y, Akiba T, Yanaga K (2013) Usefulness of circulating tumor cells after preliminary chemotherapy for prediction of response to further anticancer therapy in patients with initially unresectable metastatic colorectal cancer. Anticancer Res 33: 1769-1772.

Rahbari NN, Aigner M, Thorlund K, Mollberg N, Motschall E, Jensen K, Diener MK, Buchler MW, Koch M, Weitz J (2010) Meta-analysis shows that detection of circulating tumor cells indicates poor prognosis in patients with colorectal cancer. Gastroenterology 138: 1714-1726.

Rees M, Tekkis PP, Welsh FK, O'Rourke T, John TG (2008) Evaluation of long-term survival after hepatic resection for metastatic colorectal cancer: a multifactorial model of 929 patients. Ann Surg 247: 125-135.

Saltz LB, Cox JV, Blanke C, Rosen LS, Fehrenbacher L, Moore MJ, Maroun JA, Ackland SP, Locker PK, Pirotta N, Elfring GL, Miller LL (2000) Irinotecan plus fluorouracil and leucovorin for metastatic colorectal cancer. Irinotecan Study Group. N Engl J Med 343: 905-914.

Seeberg LT, Waage A, Brunborg C, Hugenschmidt H, Renolen A, Stav I, Bjornbeth BA, Brudvik KW, Borgen EF, Naume B, Wiedswang G (2014) Circulating tumor cells in patients with colorectal liver metastasis predict impaired survival. Ann Surg.

Stebbing J, Harding V, Urch CE, Kaier T, Schofield G, Flook M, Alifrangis C, Young AM, Shaw JA, Coombes RC, Krell J (2014) The prognostic role of circulating tumor cells in heavily pretreated individuals with a low life expectancy. Future Oncol; e-pub ahead of print 30 May 2014.

Strijbos MH, Gratama JW, Schmitz PI, Rao C, Onstenk W, Doyle GV, Miller MC, de Wit R, Terstappen LW, Sleijfer S (2010) Circulating endothelial cells, circulating tumour cells, tissue factor, endothelin-1 and overall survival in prostate cancer patients treated with docetaxel. Eur J Cancer 46: 2027-2035.

Tol J, Koopman M, Miller MC, Tibbe A, Cats A, Creemers GJ, Vos AH, Nagtegaal ID, Terstappen LW, Punt CJ (2010) Circulating tumour cells early predict progression-free and overall survival in advanced colorectal cancer patients treated with chemotherapy and targeted agents. Ann Oncol 21: 1006-1012.

Topal B, Aerts JL, Roskams T, Fieuws S, van Pelt J, Vandekerckhove P, Penninckx F (2005) Cancer cell dissemination during curative surgery for colorectal liver metastases. Eur J Surg Oncol 31: 506-511.

Vlems FA, Diepstra JH, Punt CJ, Ligtenberg MJ, Cornelissen IM, van Krieken JH, Wobbes T, van Muijen GN, Ruers TJ (2003) Detection of disseminated tumour cells in blood and bone marrow samples of patients undergoing hepatic resection for metastasis of colorectal cancer. Br J Surg 90: 989-995. Wong SL, Mangu PB, Choti MA, Crocenzi TS, Dodd 3RD GD, Dorfman GS, Eng C, Fong Y, Giusti AF, Lu D, Marsland TA, Michelson R, Poston GJ, Schrag D, Seidenfeld J, Benson 3RD AB (2010) American Society of Clinical Oncology 2009 clinical evidence review on radiofrequency ablation of hepatic metastases from colorectal cancer. J Clin Oncol 28: 493-508.

This work is published under the standard license to publish agreement. After 12 months the work will become freely available and the license terms will switch to a Creative Commons AttributionNonCommercial-Share Alike 4.0 Unported License. 